\title{
EDITORIAL
}

\section{A WORLDWIDE NETWORK FOR COMPARATIVE STUDIES ON CARAVANS: PAST, PRESENT AND FUTURE}

\author{
RED MUNDIAL PARA ESTUDIOS COMPARATIVOS SOBRE CARAVANAS: \\ PASADO, PRESENTE Y FUTURO
}

\author{
Persis B. Clarkson ${ }^{1}$, Calogero M. Santoro ${ }^{2 *}$, Thomas E. Levy ${ }^{3}$, Lautaro Núñez ${ }^{4}$, Axel Nielsen ${ }^{5}$, \\ Steven Rosen ${ }^{6}$, Frank Förster ${ }^{7,8}$, José M. Capriles ${ }^{9}$, Anatoly M. Khazanov ${ }^{10}$, Michael Frachetti ${ }^{11}$, \\ Daniela Valenzuela ${ }^{12}$, Vivien G. Standen ${ }^{12}$, Barbara Cases ${ }^{13}$, Gonzalo Pimentel ${ }^{4}$, Patrice Lecoq ${ }^{14}$, \\ Ximena Medinacelli ${ }^{15}$, Luis Briones ${ }^{16}$, André Wink ${ }^{17}$, Nicholas Tripcevich ${ }^{18}$, Heiko Riemer ${ }^{19}$, \\ Enelidolfo O'Ryan ${ }^{16}$, Ximena Loayza ${ }^{16}$, Thomas F. Lynch ${ }^{20}$, and Helina Woldekiros ${ }^{21}$
}

Caravans are historically specific and can be found in arid lands and mountains of different parts of the world, sharing characteristics such as domesticated animals with specific morphologies
Las caravanas con sus particularidades históricas se encuentran en tierras áridas y montañosas de diferentes partes del mundo. Comparten rasgos comunes tales como: animales domesticados con

1 Department of Anthropology, University of Winnipeg, 515 Portage Avenue, Winnipeg, Manitoba, Canada. p.clarkson@uwinnipeg.ca

2 Instituto de Alta Investigación, Universidad de Tarapacá, Antofagasta 1520, Arica, Chile.

*Corresponding author: calogero_santoro@yahoo.com

3 Department of Anthropology, University of California, San Diego, 9500 Gilman Drive, La Jolla, CA, USA. tlevy@ucsd.edu

4 Instituto de Arqueología y Antropología, Universidad Católica del Norte, Calle Gustavo Le Paige No 380, San Pedro de Atacama, Chile. lautaro.nunez@hotmail.com; gepimentel@ucn.cl

5 Instituto Nacional de Antropología y Pensamiento Latinoamericano, 3 de Febrero 1378, 1426 Buenos Aires, Argentina. axelnielsen@gmail.com

6 Ben-Gurion University of the Negev, POB 653, Beersheva 84105, Israel. rosen@ bgu.ac.il

7 Heinrich Barth Institute, University of Cologne, Jenner str. 8, D-50823 Köln, Germany. frankfoerster@gmx.de

8 Egyptian Museum, University of Bonn, Regina-Pacis-Weg 7, D-53113 Bonn, Germany.

9 Department of Anthropology, The Pennsylvania State University, 409 Carpenter Building, University Park, PA 16802, USA. jmcapriles@gmail.com

10 Department of Anthropology, University of Wisconsin, Madison, 5240 William H. Sewell Social Science Building, 1180 Observatory Drive, Madison, WI 53706, USA. khazanov@wisc.edu

11 Department of Anthropology, Washington University in St. Louis, One Brookings Drive, Box 1114, St. Louis, MO, 631304899, USA. frachetti@wustl.edu

12 Departamento de Antropología, Universidad de Tarapacá, Cardenal Caro 348, Arica, Chile. dani.valenzu@gmail.com; vivien.standen@gmail.com

13 Programa de Doctorado Antropología y Arqueología, Universidad de Tarapacá, Cardenal Caro 348, Arica, Chile. barbara_cases@yahoo.es

14 Centre National de la Recherche Scientifique, Université Paris 1-Panthéon Sorbonne, UMR 8096 Archéologie des Amériques, Institut d'Art et d'Archéologie, 3 Rue Michelet, 75006 Paris, France. patricelecoq@free.fr

15 Archivo de La Paz, Av. 6 de Agosto No 2080, La Paz, Bolivia. xmedinaceli@ hotmail.com

16 Museo Municipal de Pica, Balmaceda 178, Pica, Chile. geoglifo2@gmail.com, enorvadesierto@yahoo.es; xilo_lo@ hotmail.com

17 Department of History, University of Wisconsin, 3211 Mosse Humanities Bldg, 455 N. Park St, Madison, WI, 53706, USA. awink@wisc.edu

18 Archaeological Research Facility, University of California at Berkeley, 2251 College Building, Berkeley, CA, 94720-1076, USA. tripcevich@berkeley.edu.

19 University of Cologne, Institute of Prehistoric Archaeology, African Archaeology Unit, Jennerstr. 8, D-50823, Köln, Germany. heiko.riemer@uni-koeln.de

20 Cook County Historical Society, PO Box 878, Grand Marais, MN 55604, USA. lynchthomasf@gmail.com

21 Department of Anthropology, Washington University in St. Louis, Campus Box 1114, One Brookings Drive, St. Louis, MO 63130, USA.hswoldek@wustl.edu 
and behavioural traits which impose distinctive constraints on human action; patterns of mobility associated with specialized foraging and pastoralist societies; efficient trail routes; reliance upon oases and stations that served as points of trade, exchange and caravan provisioning; representations ("art"); structures and landmarks near and/or related to caravan trails; and the rapid disappearance of these resources through modern development and destruction. Globally, there is great variability as well as similarity in caravan development, use, and structure. Organized caravans seem to have appeared as a result of complex international economies, polities, social and religious networks, and we have good archaeological, historic and ethnographic data brought to light in recent decades that has improved our understanding of the organization and use of ancient caravans worldwide, and their changes through time.

There are aspects of caravan routes and remains that are unique to certain regions, which on a gross level can be divided into Old and New World circumstances. Regional geography, natural resources and history, and political, economic, and social organization are forces behind the origin, development, and maintenance of caravans and their associated material culture, e.g., pack animals, trails, structures, camp sites, rest stops, portable artifacts, etc. (Riemer and Förster 2013). These also include the rituals involved in caravans, and the range of materials transported by caravans that are also found on caravan associated sites, such as documented in the Atacama Desert (Figure 1) region beginning in the 1960s when key research on caravans intensified (Dillehay and Núñez 1988; Núñez 1976; Núñez and Dillehay 1979), creating a continuing base for investigations (Núñez and Nielsen 2011; Pimentel et al. 2011; Valenzuela et al. 2011).

Based on these common and uncommon factors, two dozen scholars from a wide range of countries and working in different geographical areas of the planet where caravans have been known, spent three days in May 2017 exchanging information and experience about caravans at the oasis of Pica (Chile), an important node in the camelid (llama) caravan system that traversed the Atacama Desert morfologías particulares y rasgos conductuales que imponen restricciones a la acción humana; patrones de movilidad de comunidades forrajeras y pastoriles especializadas; rutas de senderos eficientes dependientes de oasis y paraderos que sirvieron como estaciones de comercio, intercambio y aprovisionamiento; representaciones ("arte"); estructuras e hitos cercanos y/o relacionados con senderos caravaneros; y su continua destrucción a consecuencia del desarrollo moderno. A nivel mundial, hay gran variabilidad, así como similitudes, en el desarrollo, uso y estructura de las caravanas. Las caravanas organizadas habrían aparecido como resultado de economías macrorregionales, entidades políticas y culturales, redes sociales y religiosas complejas. Se cuenta con datos arqueológicos, históricos y etnográficos relevados en las últimas décadas, los que han mejorado nuestra comprensión acerca de los cambios en la organización, función y uso de las caravanas en el mundo a través del tiempo.

Ciertos aspectos de las rutas caravaneras con sus rasgos y evidencias asociadas se diferencian regionalmente, que a nivel macro se distinguen de acuerdo a circunstancias específicas del Viejo y Nuevo Mundo. La geografía regional, la historia y los recursos naturales, así como la organización política, económica y social son las fuerzas que impulsan el origen, desarrollo y mantenimiento de las caravanas y de su cultura material asociada, por ejemplo animales de carga, senderos, estructuras, campamentos, paradas de descanso, artefactos portátiles, etc. (Riemer y Förster 2013). Esto también incluye los rituales y una gama de materiales transportados que se encuentran en los paraderos de las caravanas, según lo documentado en la región del desierto de Atacama (Figura 1) desde 1970, cuando se intensificaron las investigaciones sobre caravanas (Dillehay y Núñez, 1988; Núñez 1976; Núñez y Dillehay 1979), creando una base de investigación que continúa hasta el presente (Núñez y Nielsen 2011; Pimentel et al. 2011; Valenzuela et al. 2011).

Teniendo como antecedentes estos factores comunes y dispares, una veintena de investigadores de varios países, que trabajan en diferentes áreas geográficas del planeta, donde existen evidencias de caravanas, se reunieron tres días en el mes de mayo del 2017 intercambiando información y conocimientos acerca de este fenómeno mundial en el oasis de Pica (desierto de Atacama, Chile), un importante nodo en el sistema caravanero de camélidos (llamas) que 


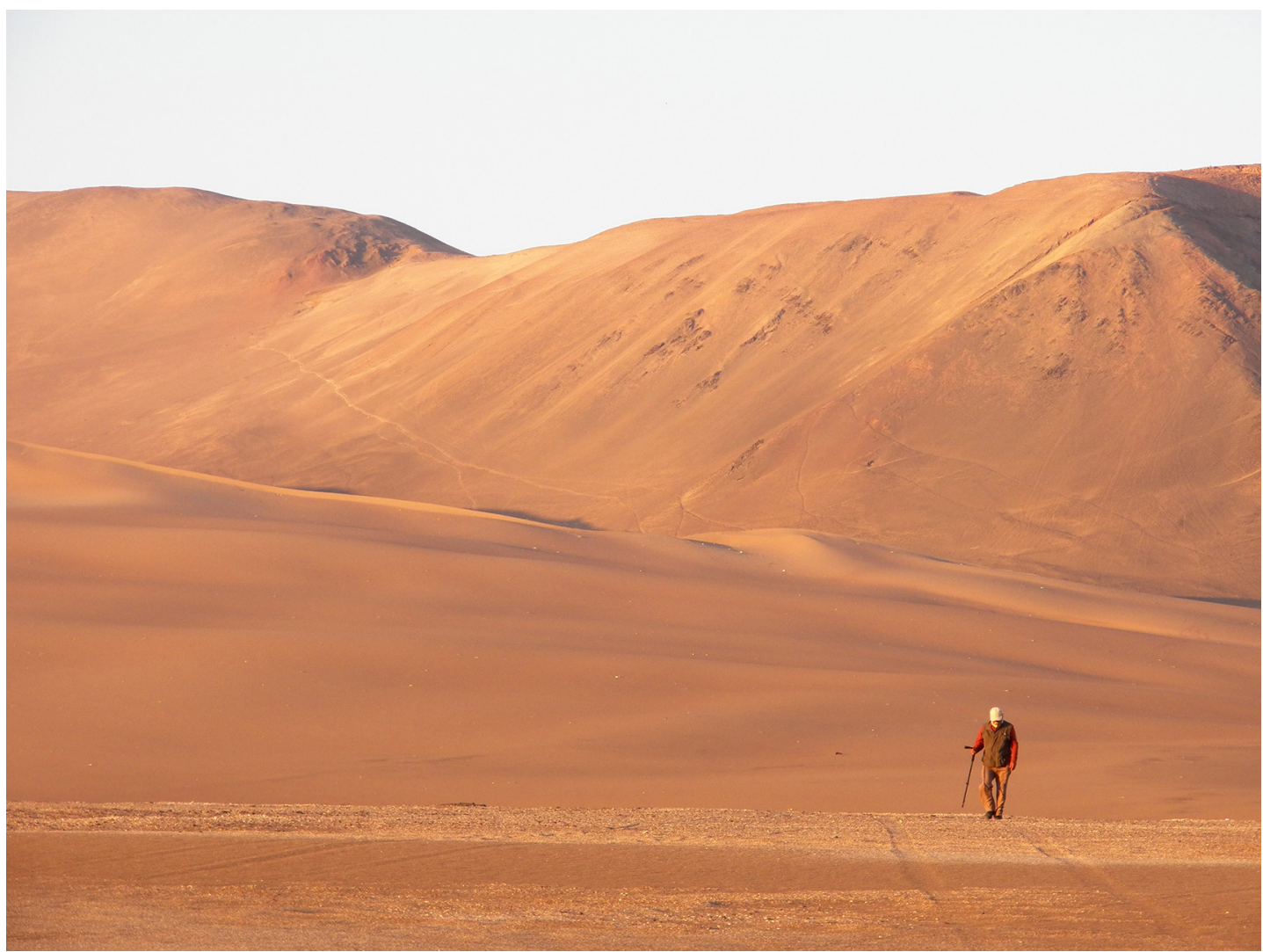

Figure 1. Luis Briones pioneer researcher on caravan trails and rock art in front of a trail in the Atacama Desert close to the Pacific Coast and Soronal Salt Plain (image courtesy of José Barraza).

Luis Briones, pionero en los estudios de huellas caravaneras y arte rupestre frente a un sendero en el desierto de Atacama, cerca del océano Pacífico y salar de Soronal (imagen cortesía de José Barraza).

for several millennia until very recent times. A former caravaner and his family -Maximiliano Mamani Mamani, his wife (warmi) Raimunda Mamani Amaro, Simón Moscoso Challapa and his warmi Eduarda Castro Challapa, originally from Llica in the highlands of Bolivia, met us at the hauntingly beautiful Cerros Pintados, an ancient caravan nexus dating back to AD 1000 (Briones et al. 2005; Clarkson 1998). The four caravaners recreated the historical setting of Andean caravan journeys for the workshop participants, beginning with a departure ceremony to safeguard the animals, cargo, and the people.

The workshop participants continued on toward the Pacific coast following old caravan trails -but this time in $4 \times 4$ vehicles. The route repeated a caravan journey taken by the same caravaners from Llica to the Pacific Ocean in 2000, accompanied at atravesó el desierto de Atacama desde hace varios milenios hasta tiempos recientes. Un ex caravanero y su familia -Maximiliano Mamani Mamani, su esposa (warmi) Raimunda Mamani Amaro, Simón Moscoso Challapa y su warmi Eduarda Castro Challapa, originarios de Llica, altiplano de Bolivia, se encontraron con nosotros en los magníficos Cerros Pintados, otro nodo de caravaneros de una antigüedad de ca. 1000 años a.p. (Briones et al. 2005; Clarkson 1998). Los caravaneros recrearon el escenario histórico de los viajes de caravanas andinas para los participantes del taller, comenzando con una ceremonia de salida para proteger a los animales, el cargamento y a la gente.

Los participantes del taller continuaron hacia la costa del Pacífico siguiendo antiguos senderos caravaneros, pero esta vez en vehículos $4 x 4$. La ruta repitió una travesía con una caravana de 
that time by several researchers who also attended the workshop (Persis Clarkson, Luis Briones, and Lautaro Núñez).

The Pica Caravan Workshop (officially "Caravan Archaeologies: En Route to the Past, Present and Future") provided for the first time an opportunity for archaeologists, historians, cultural anthropologists, art historians, and geographers to convene and analyze the evolution and role of caravans in the history of humanity on a worldwide scale. The meeting was organized as a workshop, allowing the participants to intensively converse and exchange data and ideas. Broad analogies emerged based on what we know of the lifeways of modern/historic nomads, pastoralists, and caravaners and caravans, compared with the archaeologies of nomads, pastoralists, and caravaners and caravans (Förster and Riemer 2013; Khazanov 1994). In this context, issues unfolded, such as the archaeological differences between a caravan stop and a nomadic camp in the absence of clear temporal controls, or the impact of political factors on near and distant regions. Examples of reliable versus unreliable oral narratives and the kinds of factors that may account for contrasting evidence were also discussed. Natural resources, especially oases, which were often the foci of desert trail routes, were analyzed in the context of how other natural resources like lithic materials, metals, exotic goods, water, wood, and forage were incorporated or found on trails.

Similarly, the question of how physiography and concomitant natural features like mountain passes, river fords, dune belts, pastures, and waterless regions impacted the locations of routes used and created were identified as key elements to consider in a comparative analysis (Figures 2 and 3). Evolving initially from reciprocal trade or exchange between peoples from different environmental zones, the rise of mining and the evolution of metallurgy contributed to the emergence of caravan systems that evolved among societies that become more complex and as trade or exchange expanded between regions. As well, the process of aridification and climate change was also discussed as a driving factor in the development of caravans. llamas realizada por los mismos caravaneros de Llica desde el altiplano hasta el océano Pacífico en el año 2000, acompañados en ese momento por algunos de los investigadores que asistieron al taller (Persis Clarkson, Luis Briones y Lautaro Núñez).

El taller "Caravanas Arqueológicas: En ruta hacia el pasado, el presente y el futuro”, proporcionó por primera vez una oportunidad para arqueólogos, historiadores, antropólogos culturales, historiadores del arte y geógrafos, de reunirse y analizar la evolución y la función de las caravanas en la historia de la humanidad a escala mundial. La reunión se organizó como taller, para permitir a los participantes mantener conversaciones extendidas para el intercambio de datos e ideas. Amplias analogías surgieron sobre la base de exponer los estilos de vida de pastores, caravaneros y caravanas nómades modernos/históricos, comparados con nómades, pastores, caravaneros y caravanas arqueológicas (Förster y Riemer 2013; Khazanov 1994). En este contexto, se desarrollaron temas tales como las diferencias arqueológicas entre un paradero de caravana y un campamento nómada, en ausencia de claros controles temporales, o el impacto de factores políticos en regiones cercanas y distantes. También se discutieron ejemplos de narrativas orales fiables y no confiables y los factores que pueden explicar las contradicciones. Se analizaron los recursos naturales, especialmente el rol de los oasis, que frecuentemente fueron puntos centrales en las rutas de senderos del desierto dentro del contexto de cómo otros recursos naturales como materiales líticos, metales, productos exóticos, agua, madera y forraje se incorporaron o se encontraron en los senderos.

De manera similar, la cuestión de cómo la fisiografía y las características naturales concomitantes como pasos de montaña, vados, cinturones de dunas, pastos y regiones sin agua, afectaron la ubicación de las rutas usadas y se relevaron como elementos fundamentales a considerar en un análisis comparativo (Figuras 2 y 3). Inicialmente, el comercio recíproco o el intercambio entre pueblos de diferentes zonas medioambientales, el surgimiento de la minería y la evolución de la metalurgia contribuyeron a la aparición de sistemas caravaneros que luego se desarrollaron en comunidades que se hicieron más complejas y se expandía el comercio interregional. Asimismo, se discutió el proceso de aridización y cambio climático como factores influyentes en el desarrollo de las caravanas. 


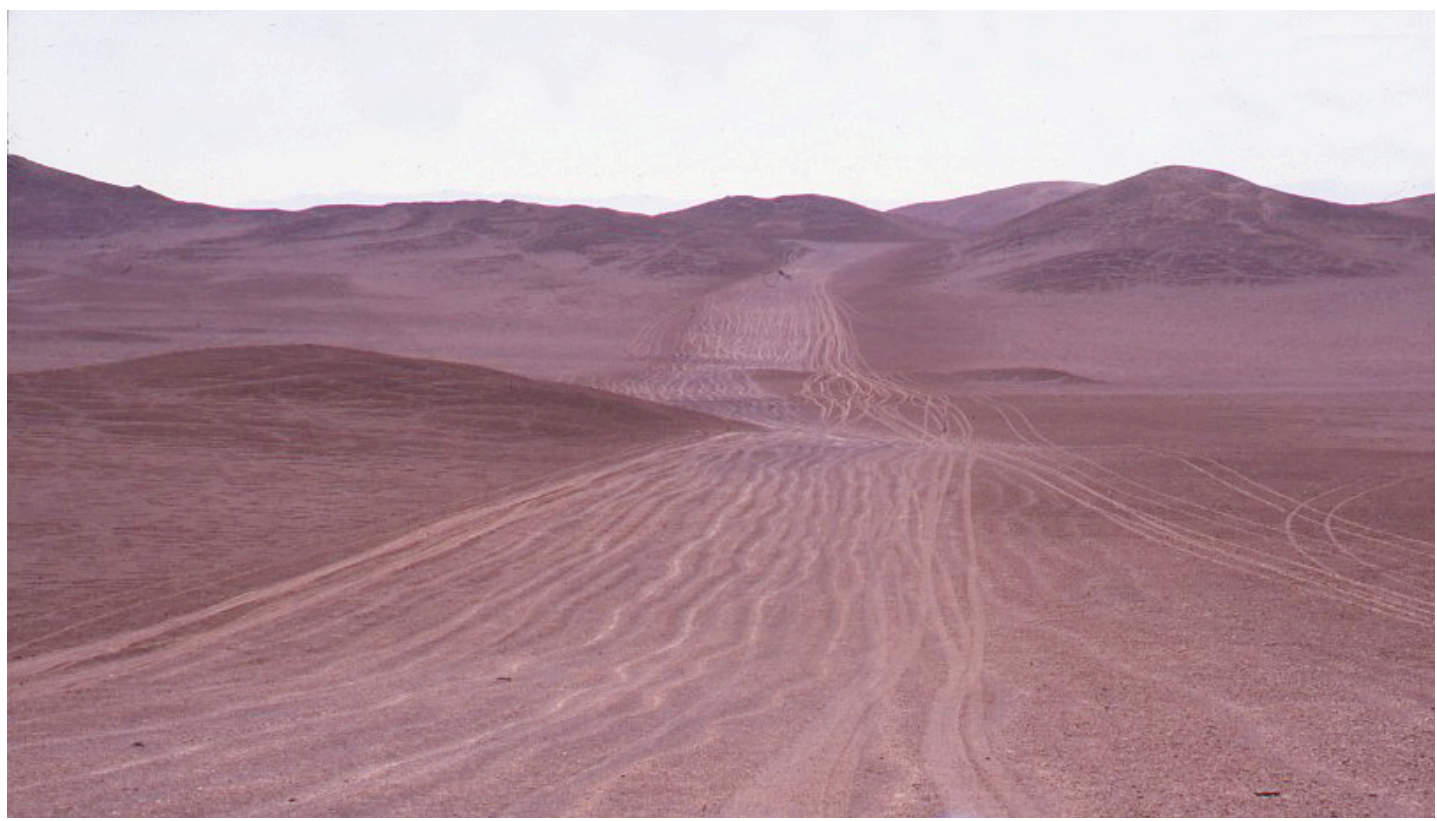

Figure 2. Caravan trails re-used by modern vehicles, a worldwide problem as seen in the ancient traces of the Loa river, Atacama Desert coast, northern Chile (image courtesy of Lautaro Núñez).

Senderos caravaneros reutilizados por vehículos modernos, un problema mundial como se observa en las huellas milenarias del río Loa, costa del desierto de Atacama, norte de Chile (imagen cortesía de Lautaro Núnez).

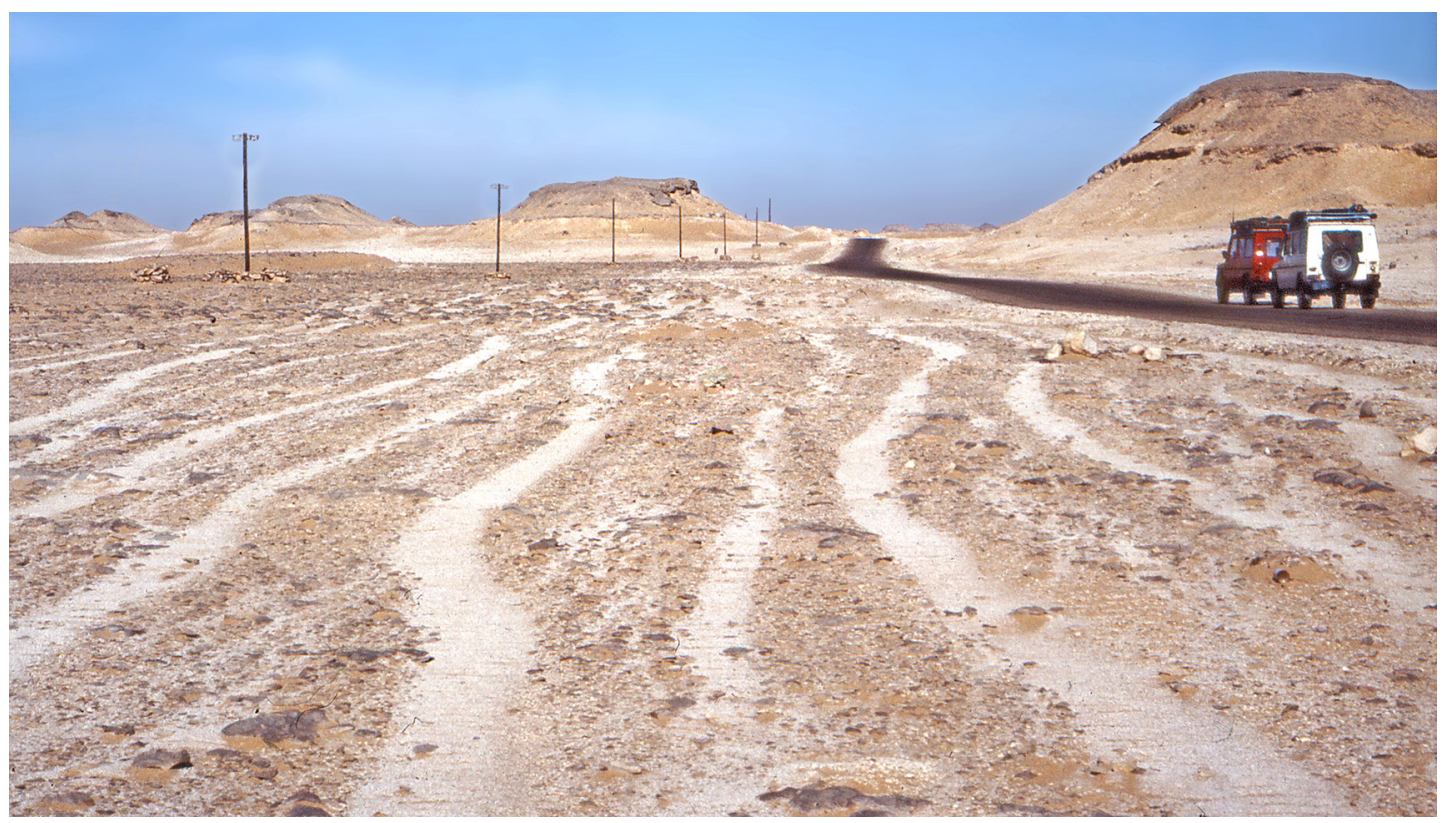

Figure 3. Caravan trails re-used and paved by modern roads as seen here in Kharga Oasis in the southernmost of Egypt (image courtesy of R. Kuper).

Senderos caravaneros reutilizados y pavimentados por rutas modernas como se observa aquí en el oasis de Kharga en el extremo sur de Egipto (imagen cortesía de R. Kuper). 
Ancient routes located throughout the Old and New Worlds were presented and analyzed by the participants via the imagery, material culture, and spatial patterns that have been found in association with caravan routes, and various interpretive models were discussed. What, if anything, influences the distribution of caravanrelated features and refuse? Are such objects found off-trail as well as on? What can we identify about en-route ritual behaviors? What kinds of evidence of non-campsite activities exist (sensu stricto)?

Two complementary approaches were used to present the topics of the workshop. Some participants focused on the behavioral and material details of caravan journeys (Andes, northeast Africa). Others emphasized the political economy of trade in which caravans operated (Middle East, Africa, Asia, and Canada). It is remarkable that, despite the fact that the historical processes of the Atacama Desert were completely independent of the rest of the world, there are similarities in the way caravans evolved and were organized in the Andes compared with northern Africa, the southern Levant, Eurasia and northern Canada.

Combining Old and New World modern, historic and ethnographic data makes it clear that ancient caravan traffic can be archaeologically attested based upon the physical remains associated with ancient caravan trails and physical remains such as campsites and way stations or caravanserais documented in Eurasia since the 9th century, and complemented by the behaviors associated with modern and historic caravan trails and traffic, like the rituals performed before caravaners set out.

For instance, the progression between nomadic lifeways (e.g., New World Paleo-Indian and Archaic, and Old World hunter-gatherers and Neolithic) and the development of nomadism within the settled world in both the New and Old Worlds (Khazanov 2009; Levy 1983; Lynch 1983), can be and is documented through a spectrum of ethnographic and ethnohistoric modeling of archaeological trajectories, as well as other interdisciplinary research strategies, which show certain convergences in terms of social complexity, and the political, economic, and social structures around caravan trade and exchange.
Se presentaron y analizaron rutas antiguas ubicadas a lo largo del Viejo y Nuevo Mundo, a través de imágenes, material cultural y patrones espaciales que se han encontrado en asociación con las rutas caravaneras y se discutieron varios modelos interpretativos. ¿Qué influye, si acaso influye en algo, la distribución de rasgos relacionados con las caravanas y sus desechos?, ¿ se encuentran tales objetos dentro y fuera de los senderos?, ¿qué podemos establecer sobre los comportamientos rituales en ruta?, ¿qué tipo de evidencia de actividades no-domésticas existen en los campamentos (sensu stricto)?

Se utilizaron dos estrategias complementarias para presentar los temas del taller. Algunos participantes se enfocaron en los detalles conductuales y materiales de las travesías caravaneras (Andes, noreste de África). Otros resaltaron la economía política del comercio en el que operaban las caravanas (Medio Oriente, África, Asia y Canadá). Es extraordinario que, a pesar de que los procesos históricos del desierto de Atacama se desarrollaron independientes del resto del mundo, hay similitudes en la manera en que evolucionaron y se organizaron las caravanas en los Andes comparado con el norte de África, el Levante meridional, Eurasia y el norte de Canadá.

La combinación de datos históricos, actuales y etnográficos del Viejo y Nuevo Mundo, dejó en claro que el antiguo tráfico de caravanas se puede confirmar arqueológicamente en base a evidencias físicas asociadas con antiguos senderos tales como campamentos y estaciones de paso formales o puestos de descanso o caravasares documentados en Eurasia desde el siglo IX. Esta información se puede complementar con las actividades ceremoniales realizadas por caravaneros actuales e históricos, como los ritos practicados antes del inicio de una travesía.

Por ejemplo, la progresión hacia estilos de vida nómadas (p.ej. cazadores-recolectores Paleoindios y Arcaicos del Nuevo Mundo y cazadores recolectores - Neolíticos del Viejo Mundo) y el desarrollo del nomadismo dentro del mundo sedentario tanto en el Nuevo como en el Viejo Mundo (Khazanov 2009; Levy 1983; Lynch 1983), puede ser documentado a través de un espectro de modelos etnográficos, etnohistóricos $y$ de trayectorias arqueológicas, así como de otras estrategias de investigación interdisciplinarias. Estas estrategias demuestran ciertas convergencias en cuanto a la complejidad de las estructuras políticas, económicas, religiosas y sociales en el entorno del comercio y el intercambio caravanero. 
In terms of ancient caravans that arose in conjunction with the emergence of complex economies, they seem to have developed from an older form of trade and exchange, and at least two types of caravans can be distinguished: (1) transit caravans that crossed desert areas between settled, mountainous and stepped areas, and (2) intermediate caravans that connected a resource region to the consumers in another region. The range of cultural features that characterize caravan routes includes watering areas, caravan campsites, formal way stations or caravanserais, roads, towns, cities, trail markers, graffiti, various kind of rock art and geoglyphs, and inadvertent archaeological remains such as artifact drop spots and runnels caused by the physical passage of the animals, people, and sometimes vehicles (Riemer and Förster 2013).

The use of pack animals was crucial in the development of archaeological caravans throughout the world, although goods transported exclusively by humans played an important role as well, particularly in the Andes. The presence of pack animals implied the taming and eventual domestication of wild animals, which serves to set a minimum date for the beginning of animal caravans. Domesticated animals were essential in the development of caravan systems, and served a variety of social, economic, and ideological functions. Donkeys were the first pack animals domesticated in the Old World around 6000 to 5000 BP (Förster 2015), while dromedaries, domesticated quite late, were fully integrated into trade systems around 3000 BP (Lhote 1987), and bactrians possibly later.

Additionally, horses, cattle, yaks and goats were also used for transportation. In western South America, and particularly in the South Central Andes (i.e., western Bolivia, southern Peru, northwestern Argentina and northern Chile), domestication of wild camelids (guanaco) into llamas occurred 7000 to $6000 \mathrm{BP}$, and they started to be used as cargo animals in caravans around 5000 to 4000 BP (Mengoni and Yacobaccio 2006; Núñez et al. 2010). The domestication of camelids and the use of llama cargo began in the highlands of the Atacama Desert toward the late Archaic period and the early Formative transition. This marked the beginning
En cuanto a las caravanas antiguas que surgieron con la aparición de economías complejas, parece ser que se desarrollaron a partir de formas más antiguas de comercio e intercambio, por lo que se pueden distinguir al menos dos tipos de caravanas: (1) caravanas en tránsito que cruzaban zonas desérticas entre zonas con asentamientos humanos, montañas y estepas y (2) caravanas intermedias que transportaban recursos de una región con consumidores de otra región. La gama de características culturales que caracterizan las rutas caravaneras incluye áreas de riego, campamentos, estaciones de paso o caravasares, carreteras, pueblos, ciudades, marcadores de sendero, grafiti, diversos tipos de arte rupestre y geoglifos y restos arqueológicos inadvertidos, como lugares para dejar artefactos y depresiones pequeñas causadas por el paso físico de los animales, personas y, a veces, vehículos (Riemer y Förster 2013).

El uso de animales de carga fue fundamental para el desarrollo de caravanas arqueológicas en todo el mundo, sin embargo, también desempeñaron una función importante los productos transportados exclusivamente por seres humanos, especialmente en los Andes. La presencia de animales de carga implicó la domesticación de animales silvestres. Esto nos ayuda a fijar una fecha mínima para el comienzo de caravanas con apoyo de animales. Éstos fueron esenciales para el desarrollo de los sistemas de caravanas y servían una variedad de funciones sociales, económicas e ideológicas. Los burros fueron los primeros animales de carga domesticados en el Viejo Mundo alrededor de 6000 a 5000 años a.p. (Förster 2015), mientras que los dromedarios, que se domesticaron mucho después, se integraron completamente en los sistemas comerciales alrededor de 3000 años a.p. (Lhote 1987) y los bactrianos (camellos) posiblemente más tarde. Asimismo, también se usaban caballos, vacunos, yaks y chivos para el transporte. En el oeste de Sudamérica, en particular en el área sur andina (oeste de Bolivia, sur de Perú, noroeste de Argentina y norte de Chile), la domesticación de camélidos silvestres (guanaco) a llamas ocurrió entre 7000 y 6000 años a.p. y comenzaron a usarse como animales de carga en caravanas aproximadamente entre 5000 a 4000 años a.p. (Mengoni y Yacobaccio 2006; Núñez et al. 2010). La domesticación de camélidos y el uso de llamas de carga comenzaron en el altiplano del desierto de Atacama durante la transición del período Arcaico Tardío al Formativo Temprano. Esto 
of long and short distance caravan movements in the South Central Andes (Cartajena et al. 2007). In other words, no sustained caravan trade could have existed without pack animals, generating a significant social impact in the histories of the Andes (Bonavia 2008) and the Old World.

In different parts of the world, long distance trade and exchange had deep roots in antiquity along what would become the so-called silk road (Hansen 2012). These economic transactions can be traced back to at least $4500 \mathrm{BP}$ and even earlier (Frachetti et al. 2017), considering that obsidian was moving $800-1000 \mathrm{~km}$ at least as early as $9500 \mathrm{BP}$. In the same period and earlier, shells and greenstone beads were also moving hundreds of kilometers, all before domesticated pack animals (Rosen 2016), and likely predating formalized caravans.

Similarly, in South America, sites along caravan trails show temporal and cultural continuity since the late Archaic in the circumpuneña area through hunter-gatherers who transported obsidian, shells, wood and other materials for hundreds of kilometers along and across the Andes and the Pacific coast. Humans transported cargo over long distances prior to the establishment of routine llama caravans, a practice that continued after llamas were employed for cargo transport (Cases et al. 2008; Cortegoso et al. 2016; Méndez et al. 2012; Núñez et al. 2017; Pimentel et al. 2011; Standen et al. 2017; Tripcevich 2010).

Thus, we can argue that caravan trade and exchange, whether it developed along silk trade routes in Eurasia, or stemmed from earlier huntergatherer modes of mobility in the Andes or in Saharan regions in northern Africa (Förster 2015), is linked to the ecology of mountains, deserts, and steppes, and to the populations who inhabited these regions from ancient to modern times. We must not forget, however, the myriad cultural and social factors embedded in caravan practices that were crucial in shaping the different caravan systems, and which explain, in part, the variations. These include, for example, the rituals performed prior to and during a caravan journey. In the Andes the journey itself is the greatest rite of the Andean llameros. So far, there is scant archaeological marcó el comienzo de movimientos de caravanas a larga y corta distancia en el área centro-sur de los Andes (Cartajena et al. 2007). En otras palabras, no podría haber existido intercambio caravanero sostenible sin el uso de animales de carga, lo que produjo un gran impacto social en las historias de los Andes (Bonavia 2008) y del Viejo Mundo.

En distintas partes del mundo, el comercio y el intercambio a larga distancia estuvieron profundamente enraizados en la antigüedad a lo largo de lo que se llamaría la ruta de la seda (Hansen 2012). Estas transacciones económicas se remontan a por lo menos 4500 años a.p. y aún antes (Frachetti et al. 2017), considerando que ya para 9500 años a.p. se transportaba obsidiana de 800-1000 km. Durante ese mismo período y antes, conchas y cuentas de piedras verdes también se transportaban cientos de kilómetros, todo esto antes de que hubiera bestias de carga domesticadas (Rosen 2016), y probablemente antes de las caravanas formales.

Igualmente, en Sudamérica, los sitios a lo largo de los senderos caravaneros demuestran continuidad temporal y cultural de prácticas que se remontan al arcaico tardío en la circunpuna en contexto de cazadores-recolectores de transportar obsidiana, conchas, madera y otros materiales por cientos de kilómetros a lo largo y a través de los Andes y de la costa del Pacífico. Los seres humanos transportaban cargas a largas distancias antes del establecimiento de caravanas rutinarias de llamas, una práctica que continuó después de que las llamas fueran empleadas para transportar carga (Cases et al. 2008; Cortegoso et al. 2016; Méndez et al. 2012; Núñez et al. 2017; Pimentel et al. 2011; Standen et al. 2017; Tripcevich 2010).

Consecuentemente, podemos argumentar que el comercio y el intercambio caravanero ya sea desarrollado a partir de las rutas comerciales de la seda en Eurasia, o de los modos de movilidad de los cazadores recolectores en las regiones andinas o saharianas del norte de África (Förster 2015), está vinculado a ecologías de montañas, desiertos y estepas y a poblaciones que habitaban estas regiones desde la antigüedad hasta tiempos actuales. No debemos olvidar, sin embargo, los innumerables factores culturales y sociales incrustados en las prácticas caravaneras que fueron fundamentales en la creación de los diferentes sistemas caravaneros y que explican, en parte, sus variaciones. Estos incluyen, por ejemplo, los ritos realizados antes, durante y fin de una travesía. En los Andes el viaje mismo es el rito 
evidence of caravan-associated rituals in the Old World. However, according to some rock art found along Saharan routes, wishes for divine protection of the travellers are attested as early as the late 5th millennium BP (Förster 2015).

In sum, by intensely discussing the most recent evidence available on caravan trails and related features, and the circumstances and characteristics of their origins in the Old and New Worlds, it was concluded that more discussion on the concept of "caravan" should be undertaken, including the consideration of global historical and regional perspectives. For example: Do we include animals as a defining condition, linked only to pack animals? Do any groups of humans carrying goods -like the ancient Aztec pochteca of Mexico, Nepalese Sherpa porters, or pilgrims travelling in a large group- form a caravan, and are the related social, economic and political factors sufficiently similar to those of animal caravans to include them within a similar category? How do we define the relationships between agricultural and caravan-type goods with the structure of caravan exchanges and their loci (nodes, villages, and patio exchange)? How do we recognize the dynamic social relationships between caravan groups with other modes of travelers of non-caravan societies? What was the role and importance of textiles made of silk or wool in the Old and New Worlds traded or exchanged via caravans? What factors initiated the use of caravans? What was the nature of the interactions between the social groups involved in the caravan world? Does a typical set of cultural features accompany physical evidence of caravans, such as cairns, apachetas (Andean; alamat in Arabic), rock art and ritual associated with caravan movements? How did the availability of various pack animal species (donkeys, camels, llamas, etc.) impact the choice of routes and efficiency of caravan traffic and trade in terms of pace and amount of freight? What is being and should be done to deal with the destruction, preservation, and conservation of caravan trails and associated sites (e.g., geoglyphs in the Atacama Desert that require immediate and more sustained attention, or caravan trails re-used and paved as modern roads worldwide? (Figures 2 and 3). más importante de los llameros andinos. Hasta el momento, hay poca evidencia arqueológica de ritos asociados con caravanas en otras partes del mundo. Sin embargo, según el arte rupestre registrado a lo largo de rutas saharianas, los deseos de protección divina de los viajeros se detecta ya hacia finales del quinto milenio a.p. (Förster 2015).

En resumen, al discutir intensamente las evidencias más recientes disponibles de los senderos caravaneros, rasgos relacionados y las circunstancias y características de sus origines, en el Viejo y Nuevo Mundo, se llegó a la conclusión de profundizar la discusión sobre el concepto de "caravana", incluyendo la consideración de perspectivas históricas y regionales mundiales. Por ejemplo: ¿Incluimos animales como condición definitoria y vinculados solo a animales de carga?, iforman caravana cualquier grupo de seres humanos transportando mercancía -como los pochteca del antiguo imperio azteca de México, o los portadores sherpas de Nepal, o los peregrinos- que viajan en grupos grandes?, ¿son los factores sociales, económicos y políticos relacionados suficientemente similares a los de caravanas de animales para incluirlos dentro de una categoría similar?, ¿cómo definimos las relaciones entre los productos agrícolas y productos de tipo caravanero con la estructura de intercambios caravaneros y sus lugares de actividad (nodos, aldeas, e intercambio local)?, ¿cómo reconocemos las relaciones sociales dinámicas entre grupos caravaneros y otros tipos de viajeros de sociedades no caravaneras?, ¿cuál fue la función y la importancia de los textiles fabricados de seda o de lana que se comerciaban o intercambiaban a través de las caravanas en el Viejo y Nuevo Mundo?, ¿qué factores provocaron el uso de caravanas?, ¿cuál fue la naturaleza de las interacciones entre los grupos sociales involucrados en el mundo caravanero?, ¿hay un conjunto típico de características culturales que acompañe la evidencia física de caravanas, como mojones, apachetas (alamat en árabe), arte rupestre y rituales asociados con el movimiento caravanero?, ¿qué impacto tuvo la disponibilidad de diversas especies de animales de carga (burros, dromedarios, camellos, llamas, etc.) en la elección de rutas y eficiencia del tráfico y el comercio caravanero en cuanto a la velocidad y la cantidad de la carga?, ¿qué se está haciendo y qué se debería hacer para abordar los temas de la destrucción, preservación y conservación de senderos caravaneros y sitios asociados (p.ej. geoglifos en el desierto de Atacama que requieren de atención 
These are some of the topics that emerged from the workshop in Pica for future collaborative research around this new worldwide network for comparative intercontinental studies on archaeological and historical caravans. In this context, it was impressive to discover that scholars from so many different parts of the globe have similar questions and concerns about the caravan world. Accordingly, a special issue with the workshop proceedings will be submitted to the journal Estudios Atacameños (Universidad Católica del Norte) to be published in 2018. Moreover, the success of the workshop and the concomitant desire to hold another workshop in the near future has lead us to explore the possibility of a dedicated volume on caravans that includes contributions from additional scholars who were not in attendance at the workshop.

Acknowledgements: Funding for this workshop was provided by the Wenner-Gren Foundation, the Social Sciences and Humanities Research Council of Canada, Research Manitoba, the University of Winnipeg, the Ilustre Municipalidad of Pica, FONDECYT Project 1151046, CONICYT/PIA Project SOC1405, the Universidad de Tarapacá, the Universidad Católica del Norte, the Consejo de la Cultura y las Artes, Región de Tarapacá, inmediata y más sostenible, o senderos caravaneros que se reutilizan y se pavimentan como caminos modernos en el mundo)? (Figuras 2 y 3 ).

Estos son algunos de los temas que surgieron del taller en Pica para posibles futuros estudios colaborativos en esta nueva red mundial para estudios intercontinentales sobre caravanas arqueológicas e históricas. En este contexto, fue sorprendente descubrir que investigadores de diversas partes del mundo tienen preguntas e inquietudes similares acerca del mundo caravanero. Por lo tanto, las actas de este taller serán presentadas como un número especial de Estudios Atacameños (Universidad Católica del Norte) a publicarse en 2018. Además, el éxito del taller y el deseo concomitante de realizar otro en el futuro cercano nos han llevado a explorar la posibilidad de editar un volumen dedicado a caravanas, que incluya, adicionalmente, contribuciones de académicos que no participaron en el taller.

the Asociación Indígena Aymara Sillajuay - Bajo Matilla, Comuna de Pica, and the Reserva Pampa de Tamarugal, CONAF (Corporación Nacional Forestal). We are grateful to Jacqueline Correa and Ximena Loayza for their superb assistance in organizing the workshop, and to Carolina Santoro for English editing of the first version of this text. The Spanish translation was done by Mónica Ruiz.

\section{References Cited}

Bonavia, D. 2008. The South American Camelids. Cotsen Institute of Archaeology, Monograph 64, University of California, Los Angeles.

Briones, L., L. Núñez, and V.G. Standen 2005. Geoglifos y tráfico prehispánico de caravanas de llamas en el desierto de Atacama (norte de Chile). Chungara Revista de Antropología Chilena 37:195-223.

Cartajena, I., L. Núñez, and M. Grosjean 2007. Camelid domestication in the western slope of the Puna de Atacama, northern Chile. Anthropozoologica 42:155-173.

Cases, B., C. Rees, G.E. Pimentel, R. Labarca, and D. Leiva 2008. Sugerencias desde un contexto funerario en un "espacio vacío" del desierto de Atacama. Boletín del Museo Chileno de Arte Precolombino 13:51-70.

Clarkson, P. 1998. Técnicas en la determinación de las edades cronológicas de geoglifos. Chungara Revista de Antropología Chilena 28:419-460.
Cortegoso, V., R. Barberena, V. Durán, and G. Lucero 2016. Geographic vectors of human mobility in the Andes (34-36 $\left.{ }^{\circ} \mathrm{S}\right)$ : Comparative analysis of 'minor'obsidian sources. Quaternary International 422:81-92.

Förster, F. 2015. Der Abu Ballas-Weg. Eine pharaonische Karawanenroute durch die Libysche Wüste. Africa Praehistorica 28:385-434.

Förster, F. and H. Riemer (eds). 2013 Desert Road Archaeology in Ancient Egypt and Beyond. Africa Praehistorica 27, HeinrichBarth-Institut, Köln.

Frachetti, M.D., C.E. Smith, C.M. Traub, and T. Williams 2017. Nomadic ecology shaped the highland geography of Asia's Silk Roads. Nature 543:193-198.

Hansen, V. 2012. The Silk Road: A New History. Oxford University Press, Oxford.

Khazanov, A.M. 1994. Nomads and the Outside World (2nd Ed). The University of Wisconsin Press, Madison. 
Khazanov, A.M. 2009. Specific characteristics of Chalcolithic and Bronze age pastoralism in the Near East. In Nomads, Tribes, and the State in the Ancient Near East: Cross-Disciplinary Perspectives, edited by J. Szuchman, pp. 119-127. The Oriental Institute of the University of Chicago, Chicago.

Levy, T.E. 1983. The emergence of specialized pastoralism in the southern Levant. World Archaeology 15:15-36.

Lhote, H. 1987. Chameau et Dromadaire en Afrique du Nord et au Sahara. Recherches sur Leurs Origines. Office National des Approvisionnements et des Servies Agricoles (ONAPSA), Paris.

Lynch, T.F. 1983. Camelid pastoralism and the emergence of Tiwanaku civilization in the South-Central Andes. World Archaeology 15:1-14.

Méndez, C.A., C.R. Stern, O.R. Reyes, and F. Mena 2012. Early Holocene long-distance obsidian transport in centralsouth Patagonia. Chungara Revista de Antropología Chilena 44:363-375.

Mengoni, G. and H.D. Yacobaccio 2006. The domestication of South American camelids. A view from the South-Central Andes. In Documenting Domestication. New Genetic and Archaeological Paradigm, edited by M. Zedar, D.G. Bradley, E. Emshwiller and B.D. Smith, pp. 228-244. University of California Press, Berkeley.

Núñez, L., I. Cartajena, C. Carrasco, P. López, P. de Souza, F. Rivera, and B.D. Santander 2017. Presencia de un centro ceremonial formativo en la circumpuna de Atacama. Chungara Revista de Antropología Chilena 49:3-33.
Núñez, L., M. Grosjean, and I. Cartajena 2010. Sequential analysis of human occupation patterns and resource use in the Atacama Desert. Chungara Revista de Antropología Chilena 42:363-391.

Pimentel, G., C. Rees, P. de Souza, and L. Arancibia 2011. Viajeros costeros y caravaneros. Dos estrategias de movilidad en el Período Formativo del desierto de Atacama, Chile. In En Ruta, Arqueología, Historia y Etnografía del Tráfico Sur Andino, edited by L. Núñez and A.E. Nielsen, pp. 43-82. Encuentro Grupo Editor, Córdoba.

Riemer, H. and F. Förster 2013. Ancient desert roads: Towards establishing a new field of archaeological research. In Desert Road Archaeology, edited by F. Förster and H. Riemer, pp. 19-58. Africa Praehistorica 27, Heinrich-Barth-Institut, Köln.

Rosen, S. 2016. Revolutions in the Desert: The Rise of Mobile Pastoralism in the Southern Levant. Routledge, New York.

Standen, V.G., C.M. Santoro, B. Arriaza, and D. Coleman 2017. Hunting, gathering, and fishing on the coast of the Atacama Desert: Chinchorro population mobility patterns inferred from strontium Isotopes. Geoarcaheology An International Journal, DOI 10.1002/gea.21594.

Tripcevich, N. 2010. Exotic goods, Chivay obsidian, and sociopolitical change in the south-central Andes. In Trade and Exchange: Archaeological Studies from History and Prehistory, edited by C.D. Dillian and C.L. White, pp. 59-73. Springer Press, New York. 
